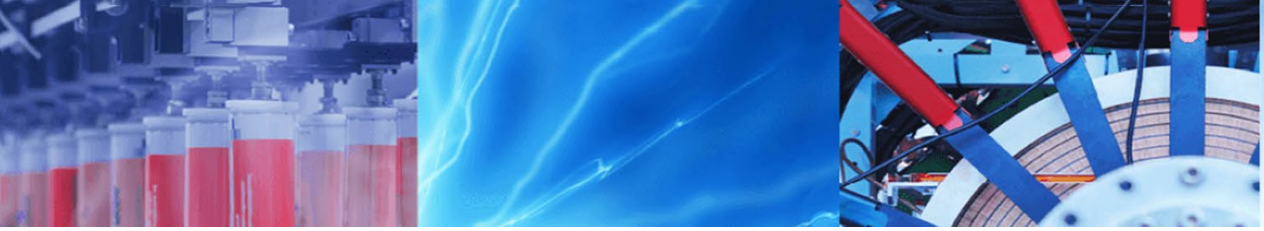

Research Article

\title{
A rapid, developed and validated RP-HPLC method for determination of azithromycin
}

\author{
Mostafa F. Al-Hakkani ${ }^{1}$ (D)
}

C) Springer Nature Switzerland AG 2019

\begin{abstract}
Azithromycin (Azr) is a member of the macrolide antibiotic and it used on a wide scale in prescribed antibiotic drugs as anti-gram-positive and anti-gram-negative microorganisms. The present study aimed to develop an HPLC method of Azr analysis enjoyed highly linearity, repeatability, robust, rugged, selective and rapid to use. The chromatographic method uses a reversed phase column ODS-3 $(250 \mathrm{~mm} \times 4.6 \mathrm{~mm} \times 5 \mu \mathrm{m})$. The mobile phase was prepared by mixing Methanol: Phosphate buffer $(9: 1, \mathrm{v} / \mathrm{v})$ at flow rate $1.2 \mathrm{ml} / \mathrm{min}$ with PDA detector $210 \mathrm{~nm}$, column oven adjusted to $40^{\circ} \mathrm{C}$ with injection volume $50 \mu \mathrm{L}$. The method revealed satisfied linearity regression $R^{2}(0.9996)$ with repeatability $(0.66 \%), L O D$ and LOQ $28.7 \mu \mathrm{g} / \mathrm{ml}$ and $86.9 \mu \mathrm{g} / \mathrm{ml}$ respectively. The method showed a successful application for Azr determination in bulk and pharmaceutical formulations.
\end{abstract}

Keywords Azithromycin · HPLC · Determination - Validation · Pharmaceutical

$\begin{array}{ll}\text { Abbreviations } \\ \text { Azr } & \text { Azithromycin } \\ \text { HPLC } & \text { High- performance liquid chromatography } \\ \text { PDA } & \text { Photodiode array detector } \\ \text { UV } & \text { Ultraviolet } \\ \text { FT-IR } & \text { Fourier-transform infrared spectroscopy } \\ \text { USP } & \text { United States Pharmacopeia } \\ \text { LOD } & \text { Limit of detection } \\ \text { LOQ } & \text { Limit of quantitation } \\ \text { Conc } & \text { Concentration } \\ \text { P. A } & \text { Peak area } \\ \text { P. As } & \text { Peak areas } \\ \text { STDEV } & \text { Standard deviation } \\ \text { RSD } & \text { Relative standard deviation }\end{array}$

\section{Introduction}

Azr is a member of the macrolide antibiotic, 15-membered azalactone ring, semi-synthetic and it is derived from erythromycin but, it differs from erythromycin in its chemical properties where the methyl-substituted nitrogen atom is incorporated into the lactone ring as shown in Fig. 1a, b.

It used for treating many and various bacterial infections, such as gram-positive and gram-negative microorganisms. The presence of the nitrogen atom into the ring introduce significant changes in the pharmacokinetics, microbiological and chemical properties of Azr [1]. It available in different oral dosage forms; powder for solution for infusion, powder for oral suspension and capsules.

Several analysis methods have been developed to determine of Azr in different pharmaceutical dosage forms. These methods include different analysis techniques as microbiological methods [2] and high-performance liquid chromatography (HPLC) [3].

Chromatographic separation technique is one of the most essential, easiest and powerful in most qualitative and quantitative analysis. HPLC is currently the most satisfied tool for an excellent and optimum separation [4].

Azr has been quantitatively analyzed in bulk material and different pharmaceutical dosage forms by

$\triangle$ Mostafa F. Al-Hakkani, mostafa.f@scinv.au.edu.eg|' Department of Chemistry, Faculty of Science, New Valley University, Al-Kharja 72511, Egypt.

SN Applied Sciences (2019) 1:222 | https://doi.org/10.1007/s42452-019-0237-6 
Fig. 1 Structure of azithromy$\operatorname{cin}(\mathbf{a})$, Erythromycin (b)

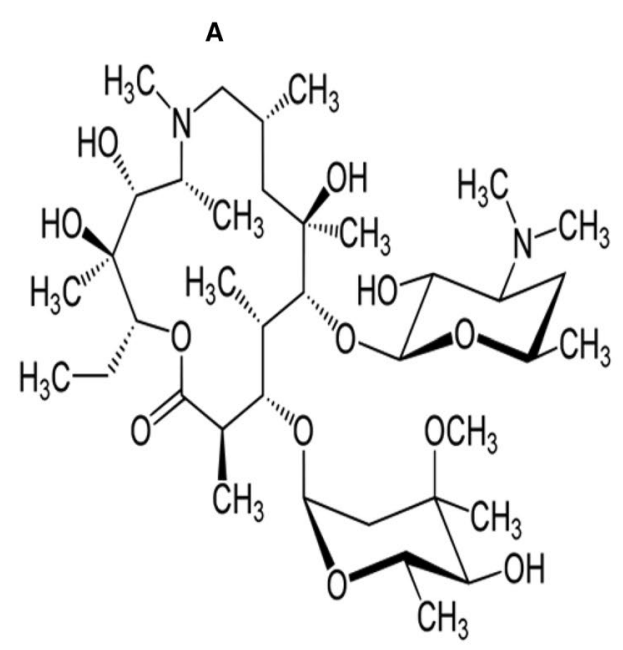

Electrochemical using coulometric and amperometric detectors [5, 6], HPLC using fluorescence [7-9].

Complicated procedures for sample pretreatment were required in detection using Fluorescence involving pre-column derivatization of the analyte. Electrochemical detection is often required a much more time in the analysis so, both in the sample preparation steps classified as a time-consuming technique and not desired in assay determination. In many HPLC assay methods of analysis, a high $\mathrm{pH}$ mobile phase about 11.0 was required. Moreover, a specific column also wanted to get the optimum separation as in the United States Pharmacopeia [10]. Mass spectrometric methods may have the highest sensitivity, but the determination process is complicated to use and very expensive [11]. A spectrophotometric UV-Vis method has been reported by Suhagia et al. for determination of Azr in pharmaceutical dosage forms. Although the method is easy and simple to perform, it suffers from the lack of separation where unknown excipients that might interfere which makes fluctuation in UV absorption reading for Azr [12]. FT-IR transmission spectroscopy for determination of Azr was reported by Mallah et al. It is easy to execute but it is not being suitable for formulations with the unknown composition of excipients [13].

In the present study, an HPLC method with a photodiode array detector (PDA) was developed for the determination of a lower concentration of Azr in different pharmaceutical dosage forms. The proposed analytical method of Azr was found to be precise, repeatable, linear, accurate, rugged, robust, specific and selective.

\section{Materials and methods}

\subsection{Chemicals and reagents}

Azr standard (98.4\%) was supplied by Century pharmaceuticals LTD. (India) as a gift sample from Smart pharma company (Assuit, Egypt). HPLC-grade methanol, HPLC-grade acetonitrile, potassium dihydrogen phosphate, Hydrochloric acid, Sodium hydroxide and Hydrogen peroxide (Scharlau, Spain). Deionized water used in the analysis. Phosphate buffer $\mathrm{pH} 8.0$ was prepared by mixing of $100 \mathrm{ml}$ of $0.2 \mathrm{M}$ potassium dihydrogen phosphate and $93.6 \mathrm{ml}$ of Sodium hydroxide $0.2 \mathrm{M}$, then diluted to $1000 \mathrm{ml}$ by deionized water.

\subsection{Instrument and chromatographic system}

Azr was measured using LC-20A HPLC instrument with the PDA (Shimadzu, Japan). The method was performed on reversed phase column ODS-3 $(250 \mathrm{~mm} \times 4.6 \mathrm{~mm} \times 5 \mu \mathrm{m})$ (Thermo Scientific, USA). The mobile phase was prepared by mixing Methanol: Phosphate buffer $(9: 1, v / v)$ at flow rate $1.2 \mathrm{ml} / \mathrm{min}$ with PDA detector $210 \mathrm{~nm}$, column oven adjusted to $40^{\circ} \mathrm{C}$ with injection volume $50 \mu \mathrm{L}$.

\subsection{Preparation of standard solution}

An accurately weighed quantity of Azr (100 mg) was transferred to a $100 \mathrm{ml}$ volumetric flask, approximately $50 \mathrm{ml}$ of the mobile phase was added and dissolved in the ultrasonic bath. The solution was completed to the marked volume by the mobile phase and mixed to obtain a final 
concentration of $1.0 \mathrm{mg} / \mathrm{ml}$. The prepared stock solution was stored at $4{ }^{\circ} \mathrm{C}$ in a glass vial.

\subsection{Method validation parameters}

\subsubsection{System suitability}

Firstly, we assured from the system suitability and the instrument performance. The sample was prepared by dissolving accurately $100 \mathrm{mg}$ of standard in $100 \mathrm{ml}$ volumetric flask and dilute with mobile phase.

\subsection{Linearity and range}

Linearity is defined by the correlation coefficient, which should be $\geq 0.999$ [14], using peak area (P. A) responses, where the range included the concentrations between the minimum and the maximum concentration in linearity test including the target concentration $(1 \mathrm{mg} / \mathrm{ml})$.

Regression linearity equation:

P. $A=a($ Conc. $)+b$

where (P. A) presents Peak area, (Conc.) presents the concentration (\%), a represents the slope and $b$ is the intercept.

Linearity was performed by preparing 5 different concentrations of $(50,80,100,120$ and 150\%) of Azr standard. The sample was prepared by weighing accurately $1000 \mathrm{mg}$ of Azr standard and dissolved in $100 \mathrm{ml}$ of mobile phase in $100 \mathrm{ml}$ volumetric flask (stock solution). Subsequently, serial dilutions were prepared by taking $(5 \mathrm{ml}, 8 \mathrm{ml}, 10 \mathrm{ml}$, $12 \mathrm{ml}$ and $15 \mathrm{ml})$ from the stock solution $(10.0 \mathrm{mg} / 1 \mathrm{ml})$ and completed to $100 \mathrm{ml}$ with mobile phase, then injected in triplicates for each concentration.

\subsubsection{Limit of detection (LOD)}

It was defined as the smallest concentration of an analyte in the sample which can be detected by the detector and it is not significant to undergo the linearity and precision test (it is not to be quantified) [15-17].

\subsubsection{Limit of quantitation (LOQ)}

It was defined as the smallest concentration of an analyte in the sample which can be detected by the detector and it can be determined quantitatively with appropriate precision and accuracy $[15,17,18]$.

LOD and LOQ were calculated according to the linearity of the calibration curve and its standard error according to the following equations:
$\mathrm{LOD}=3.3 \sigma / \mathrm{S}$

$\mathrm{LOQ}=10 \sigma / \mathrm{S}$

where $\sigma$ : is standard error and S: is a slope of the linearity calibration curve.

\subsubsection{Accuracy and recovery}

Accuracy and recovery, each of them is a face for the same coin. The accuracy of a measurement is defined as the closeness of the measured value (actual conc) to the true value (Theoretical conc) [19] where recovery it is defined as how much was recovered from the initial concentration using the purposed method [19].

Accuracy and recovery were evaluated by addition of 3 sets of Azr standard to the formula placebo to get concentration at $80 \%[0.8 \mathrm{mg} / \mathrm{ml}], 100 \%[1.0 \mathrm{mg} / \mathrm{ml}]$ and $120 \%$ $[1.2 \mathrm{mg} / \mathrm{ml}]$. Then injected in triplicate for each concentration. The average P. As for each concentration was calculated. The actual concentration for each average P. As from the linearity equation was calculated, then the recovery was calculated according to the following equation:

Recovery $\%=$ ActualConc. $\% /$ TheoreticalConc. $\% \times 100$

\subsubsection{Precision and repeatability}

Repeatability expresses "The precision under the same operating conditions over a short interval of time. Repeatability is also termed intra-assay precision" [20].

Repeatability was conducted using 6 different preparations [15] of the $100 \%$ test concentration $[1.0 \mathrm{mg} / \mathrm{ml}]$ of Azr.

\subsubsection{Robustness}

Robustness was determined by observing how a method stands up to slight variations $[14,21]$ in normal operating parameters. This could be a slight variation in mobile phase composition, temperature, flow rate and etc.

The analytical method validation was performed by deliberated changes of the target method parameters. Changes included a different organic solvent (Methanol) ratio at $( \pm 10 \%)$, different temperature $\pm 5^{\circ} \mathrm{C}$ and different flow rate $\pm 0.2 \mathrm{ml}$. where the other method parameters were kept constant in each study.

The robustness of method can be evaluated by calculation of the pooled RSD \% of the total number of replicates that have been made in each parameter change. 


\subsubsection{Ruggedness}

Ruggedness of an analytical method is the degree of reproducibility $[18,21,22]$ of the test results obtained by the analysis of the same samples under a variety of conditions. The major change such as, different analysts, HPLC columns of different serial number or different supplier, different days and etc.

(A) Day to Day: Single sample freshly preparation $(1.0 \mathrm{mg} / \mathrm{ml})$ were used to determine a single day precision then on the second day and the third day were used to provide information concerning day-to-day precision. This acquired by the same analyst.

(B) Analyst to Analyst: Person-to-person precision was performed to provide information about ruggedness values between different analysts. A single sample preparation $(1.0 \mathrm{mg} / \mathrm{ml})$ was used to determine a person precision then another person prepared another sample using the same method parameters.

(C) Column to Column:The same analytical method was performed on HPLC columns of the same packing materials but of a different serial number.

The ruggedness of method can be evaluated by calculation of the pooled RSD \% of the total number of replicates that have been made in each parameter change.

\subsubsection{Auto-sampler stability (solution stability)}

This test was performed by injection the test at a target concentration of $100 \%[1.0 \mathrm{mg} / \mathrm{ml}]$. It was injected at different time intervals to assess the solution stability at analysis conditions.

\subsubsection{Selectivity and specificity}

Selectivity means the ability to measure accurately an analyte in the presence of interference [23]. It was performed by separate injection of inactive of formulation placebo, Azr standard and formula solutions with Azr at the same test target concentration $1 \mathrm{mg} / 1 \mathrm{ml}$. Also, specificity it was performed using forced degradation to provide an indication of the stability-indicating properties of the procedure and indicating on the absence of other interference with a good separation of analyte principle peak [14, 24].

(A) Heating degradation of Azr: It was performed by weighing accurately $100 \mathrm{mg}$ in $100 \mathrm{ml}$ volumetric flask and completed with mobile phase then boiled under reflux for $5 \mathrm{~min}$, allowed to coll. Then it was injected onto HPLC.
(B) Acid hydrolysis: It was performed by weighing accurately $100 \mathrm{mg}$ of in $100 \mathrm{ml}$ volumetric flask and dissolved in $80 \mathrm{ml}$ of mobile phase then a $20 \mathrm{ml}$ of $\mathrm{HCl}$ $0.1 \mathrm{~N}$ was added and left for $15 \mathrm{~min}$, then neutralized and injected onto HPLC.

(C) Base hydrolysis: It was performed by weighing accurately $100 \mathrm{mg}$ of in $100 \mathrm{ml}$ volumetric flask and dissolved in $80 \mathrm{ml}$ of mobile phase then a $20 \mathrm{ml}$ of $\mathrm{NaOH}$ $0.1 \mathrm{~N}$ was added and left for $15 \mathrm{~min}$, then neutralized and injected onto HPLC.

(D) Oxidation hydrolysis: It was performed by weighing accurately $100 \mathrm{mg}$ of in $100 \mathrm{ml}$ volumetric flask and dissolved in $80 \mathrm{ml}$ of mobile phase then add $20 \mathrm{ml}$ of $\mathrm{H}_{2} \mathrm{O}_{2} 3 \%$ and left for $15 \mathrm{~min}$, then neutralized and injected onto HPLC.

\subsection{Application of the validated test method for Azr analysis in the different commercial dosage forms in the Egyptian local market}

The drug finished products have undergone the analysis, Zithromax $500 \mathrm{mg}$ powder for solution for infusion, Zithromax $250 \mathrm{mg}$ capsules and Zithromax $900 \mathrm{mg} / 22.5 \mathrm{ml}$ powder for oral suspension. The tested samples were prepared by dissolving an accurate quantity of the drug product in mobile phase to obtain the final concentration $1 \mathrm{mg} / \mathrm{ml}$ of Azr, then sonicated for $5 \mathrm{~min}$. Subsequently, the samples were filtered through Whatman No.1 filter paper and injected onto HPLC under the prescribed validated method parameters.

\section{Results and discussion}

\subsection{System suitability}

The retention time of Azr. peak appeared about at $5.8 \mathrm{~min}$ as in Fig. 2, also the RSD \%, tailing and plates evaluated as in Table 1. The RSD \% for each parameter of system suitability was found to be $<2.0 \%$ for 6 replicates according to the requirements in (European Pharmacopoeia [25].

\subsection{Linearity and range}

It's clear from the output results that, the method linear in the range $50-150 \%$ from the target conc $1 \mathrm{mg} / \mathrm{ml}$. Calibration curve of Azr showed also, a good regression coefficient $R^{2}$ as in Table 2 which shows the linear proportional between the response of P. As and the corresponding concentrations. So, the method was found to be linear as the $R^{2}$ is $0.9996 \geq 0.999$ and the curve follows the linear equation: P. $A=1138.1$ (Conc) +9.0828 . 


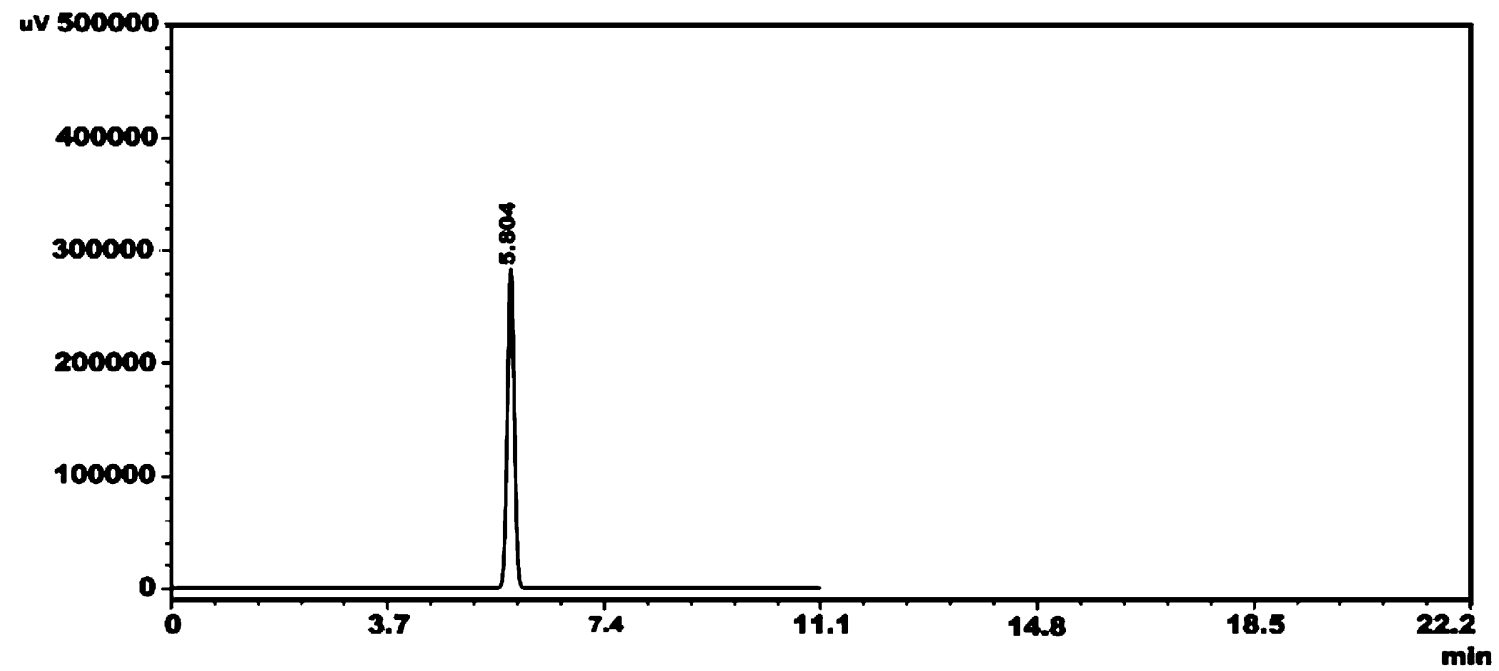

Fig. 2 Azr chromatogram

Table 1 System suitability results

\begin{tabular}{llll}
\hline$\#$ & P. A & Tailing & Plates \\
\hline 1 & 113,965 & 1.015 & 18,547 \\
2 & 113,629 & 1.015 & 18,704 \\
3 & 113,741 & 1.015 & 18,390 \\
4 & 112,509 & 1.015 & 18,613 \\
5 & 112,173 & 1.016 & 18,183 \\
6 & 113,741 & 1.016 & 18,390 \\
RSD \% & $0.12 \%$ & $0.05 \%$ & $1.02 \%$ \\
\hline
\end{tabular}

Table 2 Linearity data and parameters of Azr calibration curve

\begin{tabular}{lcll}
\hline Conc \% & Average P. As & Statistical data & \\
\hline 50 & 57,935 & $\mathrm{R}^{2}$ & 0.9996 \\
80 & 90,220 & Slope & 1138.1 \\
100 & 113,013 & Intercept & 9.0828 \\
120 & 136,478 & Standard error & 988.8 \\
150 & 171,452 & & \\
\hline
\end{tabular}

\subsection{LOD and LOQ}

LOD and LOQ values were calculated from the linearity calibration curve data of Azr and they found to be $2.87 \%$ and $8.69 \%$ from the target conc $100 \%$. That is mean LOD equal $28.7 \mu \mathrm{g} / \mathrm{ml}$ where LOQ equal $86.9 \mu \mathrm{g} / \mathrm{ml}$. These values have been indicated on the method sensitivity at lower concentrations.

\subsection{Accuracy and recovery}

The results revealed that the method was found to be accurate within the range from $80 \%(0.8 \mathrm{mg} / \mathrm{ml})$ to $120 \%$
Table 3 Accuracy and recovery of Azr results

\begin{tabular}{llcc}
\hline $\begin{array}{l}\text { Theoretical } \\
\text { conc } \%\end{array}$ & Average P. As & Actual conc \% & Recovery $\%$ \\
\hline 80 & 90,171 & 79.2 & 99.0 \\
100 & 113,890 & 100.1 & 100.1 \\
120 & 136,325 & 119.8 & 99.8 \\
\hline
\end{tabular}

Table 4 Repeatability of Azr

\begin{tabular}{llll}
\hline$\#$ & P. A & Statistical data & \\
\hline 1 & 113,965 & Average P. As & 113,293 \\
2 & 113,629 & STDEV & 752.987 \\
3 & 113,741 & RSD \% & $0.66 \%$ \\
4 & 112,509 & & \\
5 & 112,173 & & \\
6 & 113,741 & & \\
\hline
\end{tabular}

$(1.2 \mathrm{mg} / \mathrm{ml})$ of the standard conc with an addition of formula placebo as shown in Table 3.

\subsection{Precision and repeatability}

Precision was evaluated by repeatability term. Repeatability of the standard was expressed using RSD \% of P. As shown in Table 4. The obtained RSD \% of the 6 samples preparations was found to be $0.66 \% \leq 2.0 \%$ according to repeatability requirements in European Pharmacopoeia $[25,26]$. This revealed that the method was precise and repeatable. 
Table 5 Change in organic ratio results

Table 6 Change in temperature results

\begin{tabular}{llllll}
\hline$\#$ & 1 & 2 & 3 & \multicolumn{3}{l}{ Statistical data } \\
\hline Organic P. A at $900 \mathrm{ml}$ & 114,861 & 114,749 & 115,197 & Average P. As & 114,139 \\
Organic at +10\% P. A & 112,173 & 111,949 & 111,837 & STDEV & 1641.4 \\
Organic at - 10\% P. A & 115,645 & 115,533 & 115,309 & RSD \% & $1.44 \%$ \\
\hline
\end{tabular}

\begin{tabular}{llllll}
\hline$\#$ & 1 & 2 & 3 & \multicolumn{2}{l}{ Statistical data } \\
\hline Temp. P. A at $40^{\circ} \mathrm{C}$ & 114,861 & 114,749 & 115,197 & Average P. As & 113,965 \\
Temp. at $40^{\circ} \mathrm{C}+5^{\circ} \mathrm{C}$ P. A & 111,725 & 111,277 & 111,389 & STDEV & 1900.7 \\
Temp. at $40^{\circ} \mathrm{C}-5^{\circ} \mathrm{C}$ P. A & 115,645 & 115,533 & 115,309 & RSD $\%$ & $1.67 \%$ \\
\hline
\end{tabular}

Table 7 Change in flow rate results

\begin{tabular}{llllll}
\hline$\#$ & 1 & 2 & 3 & \multicolumn{2}{l}{ Statistical data } \\
\hline Flow rate at 1.2 $\mathrm{ml} \mathrm{P.} \mathrm{A}$ & 114,861 & 114,749 & 115,197 & Average P. As & 114,394 \\
Flow rate at $1.0 \mathrm{ml} \mathrm{P.} \mathrm{A}$ & 116,429 & 116,317 & 116,261 & STDEV & 1967.2 \\
Flow rate at $1.4 \mathrm{ml} \mathrm{P.} \mathrm{A}$ & 112,173 & 111,949 & 111613 & RSD $\%$ & $1.72 \%$ \\
\hline
\end{tabular}

Table 8 Day-to-day precision results

\begin{tabular}{llllll}
\hline$\#$ & 1 & 2 & 3 & \multicolumn{2}{l}{ Statistical data } \\
\hline First Day P.A & 114,861 & 114,749 & 115,197 & Average P. As & 114,077 \\
$\begin{array}{l}\text { Second Day } \\
\text { P.A }\end{array}$ & 114,413 & 114,301 & 114,637 & STDEV & 965.1 \\
Third Day P.A & 112,845 & 112,621 & 113,069 & RSD \% & $0.85 \%$ \\
\hline
\end{tabular}

\subsection{Robustness}

The results of deliberated changes included organic $( \pm 10 \%)$, temperature $\pm 5^{\circ} \mathrm{C}$ and flow rate $\pm 0.2 \mathrm{ml}$ were evaluated by RDS \% calculations. The observed RSD \% results were $1.44 \%$ for change in organic ratio, $1.67 \%$ for change in temperature and $1.72 \%$ for the flow rate change.

In all case studies, the RSD $\%$ was $<2 \%$ as shown in Tables 5, 6 and 7. So, the obtained results indicating that the method is a robust.

\subsection{Ruggedness}

According to the obtained results after major changes application on the analysis method including day-to-day, analyst-to-analyst and column-to-column precisions. The method was found to be rugged as revealed results in Tables 8, 9 and 10. The ruggedness of method was evaluated using RSD \% and it was $0.85,0.31$ and $1.69 \%$ for dayto-day, analyst-to-analyst and column-to-column precisions respectively and also as in Robustness challenge all the RSD $\%<2.0 \%$.
Table 9 Analyst-to-Analyst precision results

\begin{tabular}{|c|c|c|c|c|c|}
\hline \# & 1 & 2 & 3 & Statistical dat & \\
\hline $\begin{array}{l}\text { First Analyst } \\
\text { P. A }\end{array}$ & 114,861 & 114,749 & 115,197 & Average P. As & 114,674 \\
\hline \multirow{2}{*}{$\begin{array}{l}\text { Second Ana- } \\
\text { lyst P. A }\end{array}$} & 114,637 & 114,189 & 114,413 & STDEV & 351.8 \\
\hline & & & & RSD \% & $0.31 \%$ \\
\hline
\end{tabular}

\subsection{Auto-sampler stability (solution stability)}

The test solution was found to be stable in the auto-sampler within about $12 \mathrm{~h}$ at room temperature with RSD \% equal 0.67\% as in Table 11 .

\subsection{Selectivity and specificity}

The peak of Azr was appeared well resolved from other degradation peaks and any adjacent peak with resolution at least 3.6 as in Fig. 3a, b. The results also were revealed that good assay reading after forced degradation within $5 \%$ from the initial assay P. As of Azr. So, the method was found to be specific and selective for Azr determination.

\subsection{Analysis of different commercial dosage forms "Finished products"}

The Azr average assay results of Zithromax $500 \mathrm{mg}$ powder for solution for infusion, Zithromax $250 \mathrm{mg}$ capsules and Zithromax $900 \mathrm{mg} / 22.5 \mathrm{ml}$ powder for oral suspension revealed good results; $101.4 \%, 102.2 \%$ and 99.8 respectively. 
Table 10 Column-to-Column precision results

\begin{tabular}{llllll}
\hline$\#$ & 1 & 2 & 3 & \multicolumn{3}{l}{ Statistical data } \\
\hline First Column P. A & 114,861 & 114,749 & 115,197 & Average P. As & 113,200 \\
Second Column P. A & 111,613 & 111,277 & 111,501 & STDEV & 1910.5 \\
& & & & RSD $\%$ & $1.69 \%$ \\
\hline
\end{tabular}

Table 11 Auto-sampler stability solution

\begin{tabular}{|c|c|c|c|c|c|c|}
\hline \# & $\mathrm{Oh}$ & $3 \mathrm{~h}$ & $6 \mathrm{~h}$ & $12 \mathrm{~h}$ & Statistical data & \\
\hline \multirow[t]{3}{*}{ Test P. A } & 113,405 & 112,845 & 112,397 & 111,613 & Average P. As & 112,565 \\
\hline & & & & & STDEV & 756.9 \\
\hline & & & & & RSD \% & $0.67 \%$ \\
\hline
\end{tabular}
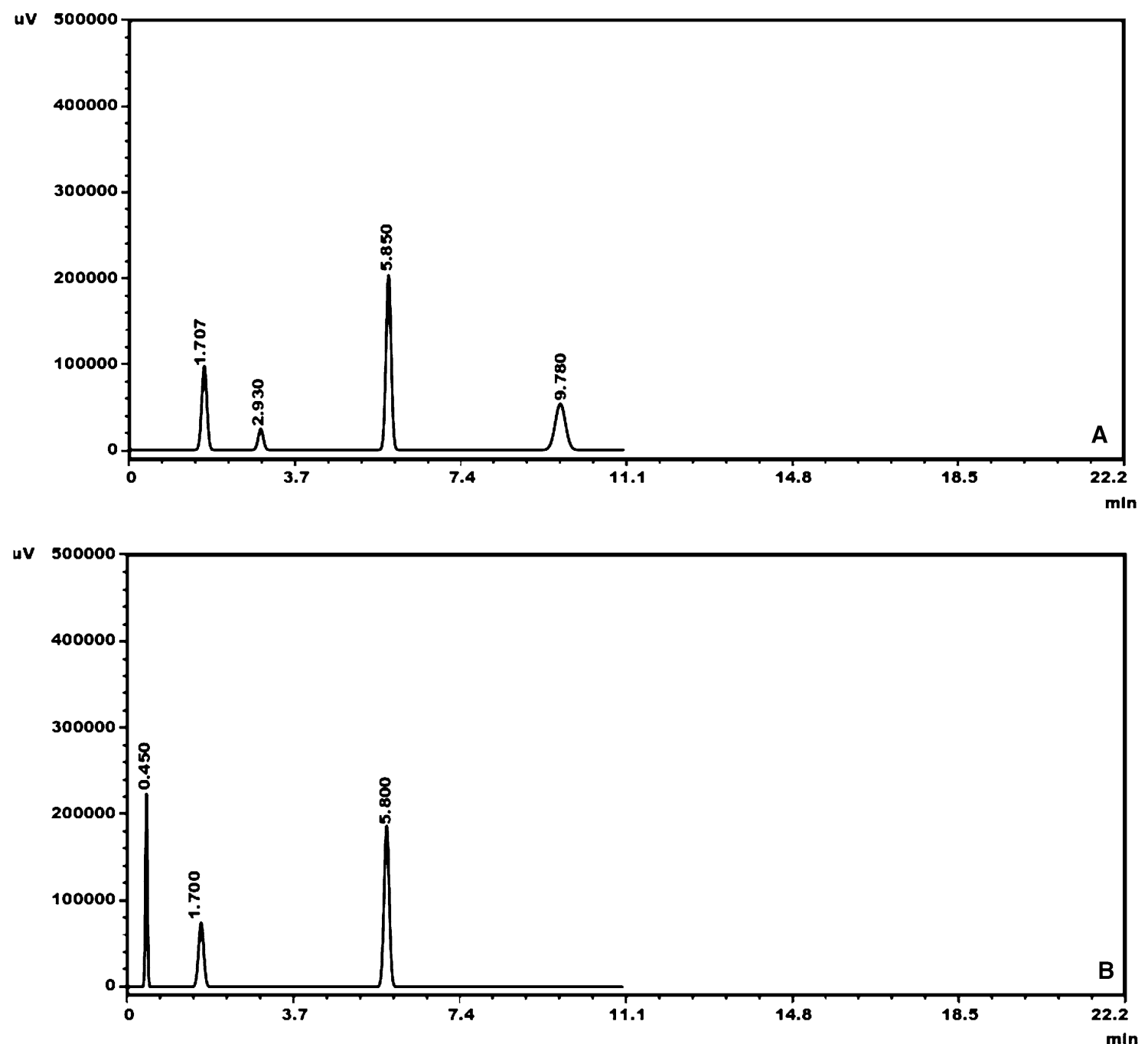

Fig. 3 Effect of heating degradation (a) and Hydrogen peroxide (b) in specificity test 


\section{Conclusion}

The present study introduces a rapid, easy, cheap and accurate method of Azr analysis. The analysis run time takes about $8 \mathrm{~min}$. The method revealed a good behaviour as linear, precise (repeatable), robust, rugged, selective and specific as the resolution factor between Azr peak and any adjacent peak at least anyway $>1.5$. LOD and LOQ also, evaluated and showed an appreciated and satisfied value as $28.7 \mu \mathrm{g} / \mathrm{ml}$ and $86.9 \mu \mathrm{g} / \mathrm{ml}$ respectively. So, the analysis method is valid to use for Azr determination at the minimum level of concentrations with convenient tools of analysis. The validated method gave satisfying results for practical application of Zithromax assay determination for three different dosage forms as revealed the results.

Acknowledgements The author presents great thanks to Smart pharma company for supporting this work.

\section{Compliance with ethical standards}

Conflict of interest The corresponding author states that there is no conflict of interest.

Human and animal rights Research is not involving Human Participants and/or Animals.

\section{References}

1. Ghari T, Kobarfard F, Mortazavi SA (2013) Development of a simple RP-HPLC-UV method for determination of azithromycin in bulk and pharmaceutical dosage forms as an alternative to the USP method. Iran J Pharm Res 12:57-63

2. Breier A, Garcia C, OppeT (2002) Microbiological assay for azithromycin in pharmaceutical formulations. J Pharm Biomed Anal 29:957-961

3. Zeng A, Liu X, Zhang S, Zheng Y, Huang P, Du K, Fu Q (2014) Determination of azithromycin in raw materials and pharmaceutical formulations by HPLC coupled with an evaporative light scattering detector. Asian J Pharm Sci 9:107-116

4. Ghodsi R, Kobarfard F, Tabatabai SA (2012) Application of narrowbore HPLC columns in rapid determination of sildenafil citrate in its pharmaceutical dosage Forms. Iran J Pharm Res 11:123-127

5. Taninaka C, Ohtani H, Hanada E, Kotaki H, Sato H, Iga T (2000) Determination of erythromycin, clarithromycin, roxithromycin, and azithromycin in plasma by high-performance liquid chromatography with amperometric detection. J Chromatogr B Biomed Sci Appl 738:405-411

6. Kees F, Spangler S, Wellenhofer M (1998) Determination of macrolides in biological matrices by high-performance liquid chromatography with electrochemical detection. J Chromatogr A 812:287-293

7. Torano JS, Guchelaar H-J (1998) Quantitative determination of the macrolide antibiotics erythromycin, roxithromycin, azithromycin and clarithromycin in human serum by high-performance liquid chromatography using pre-column derivatization with 9-fluorenylmethyloxycarbonyl chloride and fluorescence detection. J Chromatogr B Biomed Sci Appl 720:89-97

8. Bahrami G, Mirzaeei S, Kiani A (2005) High performance liquid chromatographic determination of azithromycin in serum using fluorescence detection and its application in human pharmacokinetic studies. J Chromatogr B 820:277-281

9. Bahrami G, Mohammadi B (2006) A new on-line, in-tube pre-column derivatization technique for high performance liquid chromatographic determination of azithromycin in human serum. $J$ Chromatogr B 830:355-358

10. Pharmacopoeia US (2013) National Formulary. Syst Suitabil 2:311-312

11. Mousavi SHH, Kobarfard F, Husain SW, Tehrani MS, Azar PA, Ahmadkhaniha R, Mehdizadeh A (2012) A rapid, simple, liquid chromatographic-electrospray ionization, ion trap mass spectrometry method for the determination of finasteride in human plasma and its application to pharmacokinetic study. Iran J Pharm Res 11:59-67

12. Suhagia B, Shah S, Rathod I, Patel H, Doshi K (2006) Determination of azithromycin in pharmaceutical dosage forms by spectrophotometric method. Indian J Pharm Sci 68:242-245

13. Mallah MA, Sherazi S, Mahesar SA, Rauf A (2011) Assessment of azithromycin in pharmaceutical formulation by fourier-transform infrared (FT-IR) transmission spectroscopy. Pak J Anal Environ Chem 12:61-67

14. Shabir GA (2005) Step-by-step analytical methods validation and protocol in the quality system compliance industry. J. Validat. Technol. 10:314-325

15. ICH Steering Committee (1996) ICH Q2B Validation of Analytical Procedures: Methodology, European Agency for the Evaluation of Medicinal Products, International Commission on Harmonisation, London (CPMP/ICH/281/95)

16. Guideline, ICH Harmonised Tripartite (2005) Validation of analytical procedures: text and methodology Q2 (R1), International Conference on Harmonization, Geneva, Switzerland, pp 11-12

17. Shaikh K, Patil S, Devkhile A (2008) Development and validation of a reversed-phase HPLC method for simultaneous estimation of ambroxol hydrochloride and azithromycin in tablet dosage form. J Pharmaceut Biomed 48:1481-1484

18. Chang C-C, Fan S-Y, Zang C-Z, Hsu Y-H, Lin M-C, Wang D-Y, Cheng $\mathrm{H}-\mathrm{F}$ (2019) Validation of $\mathrm{LC}$ method in determining enantiomeric purity of pramipexole using polysaccharide-derived chiral stationary phases under organic-aqueous mode. SN Appl Sci 1:50

19. Ravisankar P, Navya CN, Pravallika D, Sri DN (2015) A review on step-by-step analytical method validation. IOSR J Pharm 5:7-19

20. European Medicines Agency (1995) ICH Topic Q 2 (R1) Validation of analytical procedures: text and methodology, pp 5-12

21. Huber $L$ (1999) Validation of HPLC methods. Biopharm 12:64-66

22. Abounassif MA, Hefnawy MM, Mostafa GAE (2012) Separation and quantitation of oxprenolol in urine and pharmaceutical formulations by HPLC using a Chiralpak IC and UV detection. Monatsh Chem 143:365-371. https://doi.org/10.1007/s00706-011-0605-4

23. Vessman J (1996) Selectivity or specificity Validation of analytical methods from the perspective of an analytical chemist in the pharmaceutical industry. J Pharmaceut Biomed Anal 14:867-870

24. FDA (2000) Methods validation: chemistry, manufacturing and controls documentation, availability. Fed Regist (Notices) 65:52776-52777

25. European Pharmacopoeia (2013) Appendix III Chromatographic Separation Techniques "Ph. Eur. method 2.2.46", 7th edition

26. Latha $S$, Thangadurai SA, Jambulingam M, Sereya K, Kamalakannan D, Anilkumar M (2017) Development and validation of RPHPLC method for the estimation of Erlotinib in pharmaceutical formulation. Arab J Chem 10:S1138-S1144

Publisher's Note Springer Nature remains neutral with regard to jurisdictional claims in published maps and institutional affiliations. 